\title{
迪(1) 高分子科学最近の進歩
}

\section{薬物の経皮吸収を促進する}

高分子

\section{長瀬＼cjkstart裕／青柳 隆夫}

Yu Nagase/Takao Aoyagi, (財) 相模中央化学研究所

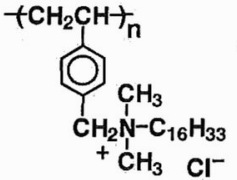

1

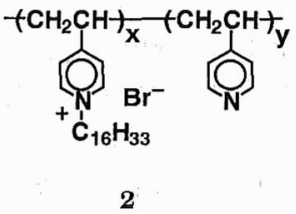

2
図 1 カチオン系界面活性哃型高分子促進剈

\section{1.はじめに}

全身作用を目的とした薬物投与方法としては，一般 に経口投与または注射による場合がほとんどである が，薬物が経口投与されると肝臓での代謝（初回通過 効果）が避けられず，また，注射による投与の場合， 生物学的半減期の短い薬物においては頻回投与が必要 となり，薬物血中濃度の維持が困難である。 そこで， 薬物を皮膚からの浸透吸収によって投与する治療シス テムが，従来法に代わる新しい薬物投与法として注目 されている1)。しかし，皮膚表面の最外層に位置する 角質層は，物質の透過に対してバリアー性を有してい るために，良好な透過性を示す一部の薬物を除いて， 治療に必要な薬物血中濃度を得るのが困難なことが多 い。そこで, 経皮吸収型製剤の実現のためにはなんら かの透過促進手段が必要となる。

促進手段のなかでも吸収促進剤の利用は最も簡便な 方法である. ジメチルスルホキシド， $N$-メチル-2ピロリドンなどの非プロトン性極性溶媒，アルコール 類, 脂肪酸, 界面活性剂(2),3), エステル類 ${ }^{4)}$ など既存 の化合物の促進剤としての効果が検討され，また，さ まざまな構造を有する新規の経皮吸収促進剤が開発さ
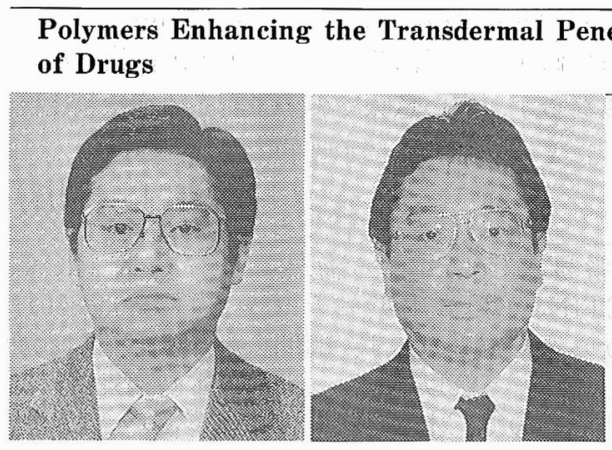

長瀬 裕 (財) 相模中央化学研究所 (229 相模原市西大沼 4-4-1) 副主任研究員, 工博 (写真左)

1977 年早大理工学部化学科卒，1982 年大学院博士課程修了。同年早大 理工学部助手, 1983 年相模中研入所. 専門は高分子合成, 機能性高分 子. 〈趣味〉野球, テニス, 旅行

青柳隆夫 同上・研究員, 工博 (写真右)

1983 年早大理工学部応用化学科卒, 1985 年大学院理工学研究科博士前 期課程修了。同年ライオン（株）入社，1986 年相模中研入所. 1993 年 東工大工博. 専門は機能性高分子: 現在の研究はドラッグデリバリーシ ステムの研究。〈趣味〉読書, スポーツ 


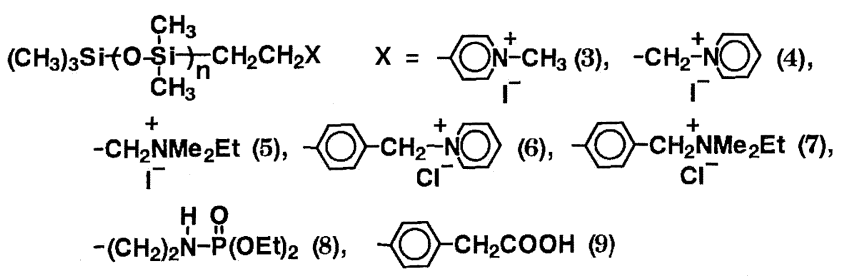

図 2 PDMS 系促進㓮

つて減少する傾向を示した。また得られたポリマーの 皮膚一時刺激性を Draize 法によって評価したとこ ろ,コントロールと差がなく, 促進剤の高分子量化に よって促進効果を保持したまま皮膚刺激性だけを回避 できることが明らかとなった。

\section{3. ポリシロキサン系促進剤}

分子内に極性，非極性部分を併せ持つ化合物は一般 に経皮吸収促進効果を示すことが知られており，その 場合, 非極性部分は長鎖アルキル基であることが多 い. 促進剤の非極性部分として疎水性の大きいポリジ メチルシロキサン（PDMS）鎖を利用すれば，長鎖ア ルキル基を有する化合物と比較して，より嵩高い分子 になると考えられる，そこで，片末端に種々の極性基 を有する PDMS を合成し，主にインドメタシン（抗 炎症薬）の経皮吸収に対する促進効果を検討し

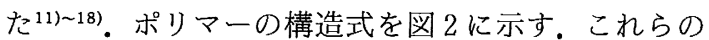
ポリマーは非極性基として PDMS を有しているため に，いわば分子サイズの大きい界面活性剤と見なすこ とができる。

片末端にメチルピリジニウム基を有する PDMS 3 をドナー部に添加したときのインドメタシンの皮膚透
過率動を図 3 (a) に示した。いずれのポリマ 一の添加によってもインドメタシンの皮䖉透 過は促進され，その効果はポリマーの平均重 合度が増加するに従って増大する傾向を示し た。この傾向は片末端にピリジニウムまたは アンモニウム基を有する PDMS 4〜7 におい ても観察された．分子量の増加とともに促進 効果が大きくなるという結果は, 塩化ベンザ ルコニウム型ポリマーとは逆の効果である. シロキサンの重合度が増すにしたがって分子 全体はより疎水性になることから，促進効果 発現には分子全体の極性が重要な因子となることが示 唆される。

一方，片末端にリン酸アミドエステル基を有する PDMS 8 や，カルボキシル基を有する PDMS 9 の場 合では, カチオン基を有する PDMS とは異なり, 重 合度が増加するに従って促進効果は逆に減少する傾向 を示した。これらのポりマーは末端に極性基を有して はいるが，分子全体としては片末端にカチオン基を有 した PDMSよりも極性は低いと考えられる。つま り，先に述べたように，促進剤の極性が促進効果と密 接な関係にあると考えられる。

薬物の経皮吸収を物理化学的に取り扱う場合，皮膚 （角質層）を均一な膜であると仮定できた時にのみ成 り立つが，Fick の式などを適用することによって得 られる情報は多い199. 定常状態における薬物の皮膚透 過速度 $d Q / d t$ は Fick の式より，

$$
\frac{d Q}{d t}=\frac{K C_{\mathrm{v}} D A}{L}
$$

で表わされる ${ }^{20)}$.ここで $K$ は薬物の基凨から皮膚表 面への分配係数， $C_{\mathrm{V}}$ はドナー中の薬物濃度， $D$ は皮 膚バリアー(角質層) 中の薬物の拡散係数，A は皮 膚透過に扔ける有効面積， $L$ は皮膚バリアーの厚さを

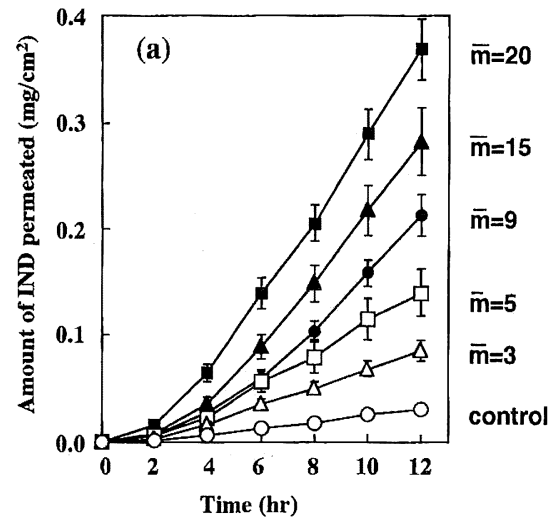

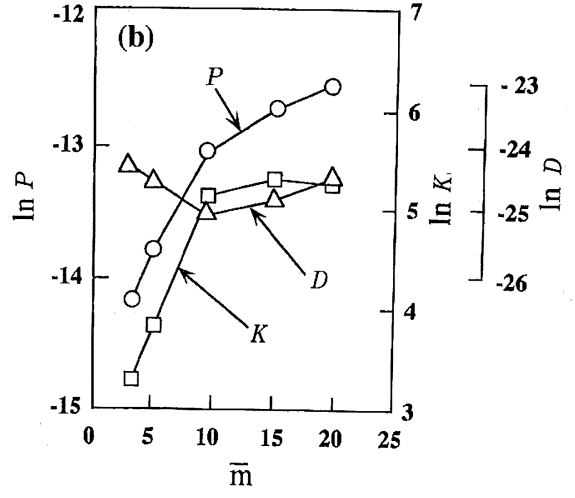

図 3

PDMS 化合物 3 を用い たインドメタシンの皮膚 透過実験結果 (a), およ び $P, D, K$ 值と 3 の平 均重合度との関係 (b) 


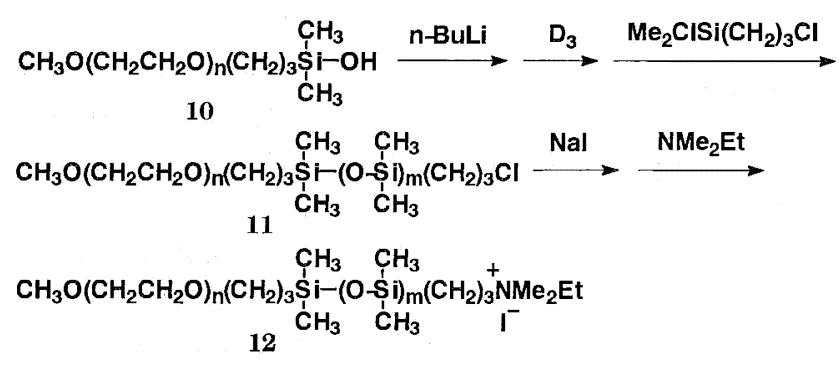

図 4 PEG/PDMS 系促進剤の合成

とが明らかとなった，また，先に述べた塩化 ベンザルコニウム型ポリマーや他のシロキサ ン系促進剤においても, 同様の結果が得られ ている.

以上の結果から，これらの高分子促進剤は 皮膚表面の角質層に吸着され薬物の皮膚表面 への分配係数を増大させることにより促進効 果を発現していることが予想される、実際 に，上記のポリマーはいずれも疎水的であ り，したがって脂溶性薬物の吸収促進には有 効であるが, 水溶性薬物の場合は効果が激減 することもわかっている。 そこで, 使用でき

表す（1）式に拈いて $P(=K D / L)$ は透過係数と定 義され, $t$ と $Q$ の関係のグラフ (例えば図 $3(\mathrm{a})$ ) の 定常状態における傾きより算出される.さらら, 定常 状態までに達する時間を考慮すれば, 薬物の透過量 $Q$ は（2）式で表される21).

$$
\begin{aligned}
Q= & \frac{K C_{\mathrm{v}} D A}{L}\left(t-\frac{L^{2}}{6 D}\right) \\
& -\frac{2 K C_{\mathrm{v}} L A}{\pi^{2}} \sum_{n=1}^{\infty} \frac{(-1)^{n}}{n^{2}} \exp \left(-\frac{D n^{2} \pi^{2} t}{L^{2}}\right)
\end{aligned}
$$

ここで各シンボルは（1）式と同じである。（2）式に おいて時間 $t$ と $Q$ の関係のグラフの $t$ 軸への外捙值 よりラグタイム $\tau=L^{2} / 6 D$ が求まり, 拡散係数 $D$ が 算出できる。また, 得られた $P, D$ 值より分配係数 $K(=P L / D)$ も得られる。このように，薬物の皮膚 透過における各段階におけるパラ メータを計算することにより促進 剤がどの過程に作用しているか評 価できると思われる。

図 3 (b) に,メチルピリジニウ 厶基を有する PDMS 3 を用いた ときのインドメタシンの皮膚透過 に抢ける透過，拡散，分配の各係 数と平均重合度の関係を示した. ポリマーの添加によって透過係数 $P$ と分配係数 $K$ は同じ傾向で上 昇したが，皮膚バリアー中での薬 物の拡散係数 $D$ は浪济一定の值 であり，この値は促進剤無添加系 と一致した。っまり，この PDMS 化合物を促進剂として用 いたときの薬物透過係数の増大は 分配係数のみの上昇に起因するも のであり，皮膚表面の角質層のバ リアー機能の低下による薬物の拡 散性の上昇によるものではないこ

\begin{tabular}{|c|c|c|c|c|c|}
\hline 促進剂 & 薬物a） & $\begin{array}{c}\text { 透過係数 } \\
P\left(\mathrm{x} 10^{-6} \mathrm{~cm} / \mathrm{s}\right)\end{array}$ & $\begin{array}{c}\text { 拡散係数 } \\
D\left(\mathrm{x} 10^{-11} \mathrm{~cm}^{2} / \mathrm{s}\right)\end{array}$ & $\begin{array}{l}\text { 分配係数 } \\
K\end{array}$ & $\begin{array}{c}\text { 溶解度 } \\
C_{\mathrm{v}}(\mathrm{mg} / \mathrm{ml})\end{array}$ \\
\hline $3(n=10)$ & IND & 2.09 & 1.23 & 169.3 & 3.41 \\
\hline $3(n=20)$ & IND & 3.55 & 1.87 & 190.2 & 3.01 \\
\hline $8(n=1)$ & IND & 5.10 & 1.12 & 413.3 & 2.49 \\
\hline $9(n=1)$ & IND & 3.17 & 1.51 & 210.7 & 2.78 \\
\hline $12(\mathrm{n}=8, \mathrm{~m}=15)$ & ANP & 4.72 & 0.91 & 517.1 & 20.0 \\
\hline $12(n=17, m=15)$ & ANP & 2.32 & 1.00 & 233.1 & 20.0 \\
\hline $13^{\mathrm{b})}$ & IND & 7.05 & 5.91 & 119.3 & 4.77 \\
\hline $14^{b)}$ & IND & 3.38 & 5.67 & 59.6 & 4.86 \\
\hline oleic acid & IND & 6.06 & 13.28 & 45.6 & 4.03 \\
\hline 無添加系 & IND & 0.22 & 2.01 & 11.0 & 4.06 \\
\hline 無添加系 & ANP & 0.50 & 1.00 & 48.6 & 20.0 \\
\hline
\end{tabular}

表 1 各促進剤を用いた薬物の皮䖉透過における $P, K, D$ 值

a) IND; インドメタシン, ANP; アンチピリン

b) 13 の化学構造;

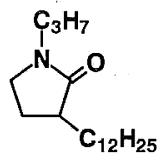

140化学構造;<smiles>CCCCNP(=O)(OCC)OCC</smiles> 
鎖, PDMS 鎖および末端のカチオン基のいずれが欠 けても促進効果が激減することがわかった。さらに, 各々の薬物において最も高い促進効果を発現する 12 の PEG 鎖や PDMS 鎖の最適な平均重合度はそれぞ れ異なることも判明した. したがって，親水性，疎水 性を問わず多くの薬物に適応できる高分子促進剤を設 計することが可能である。

\section{4. 促進風の作用機序}

高分子量の経皮吸収促進剤と低分子量促進剤との違 いを明確にするために，低分子量促進剂を用いた場合 についても薬物の皮膚透過に抢ける透過, 拡散, 分配 の各係数 $P, D, K$ の算出を行った. 用いた低分子 量の促進剤は, Azone (1-dodecylazacycloheptan-2one) ${ }^{22)}$ と類似構造を有するアルキル置換ピロリドン 誘導体 $13^{23)}$ ，リン酸アミドエステル化合物 $14^{24)}$ およ びオレイン酸である．これら化合物を用いたときのイ ンドメタシンまたはアンチピリンの皮膚透過における 各パラメータを, シロキサン系ポリマーの結果と比較 して表 1 に示した。ポリマーの場合とは異なり，これ ら低分子量の促進剤を用いると拡散係数 $D$ の上昇が 観察され, 無添加系と比較して 3〜 6 倍程度の值を示 した。これら低分子量促進剤は皮膚バリアー内に浸透 し，角質層中の脂質分子集合体に作用し流動性を増大 させ, 結果として薬物の拡散性を上昇させたものと考 えられる。一方, 高分子促進剤は $D$ を変化させずに 分配係数 $K$ のみを大幅に上昇させていることがわか る、その他，モデル脂質のゲル-液晶転移温度に対す る促進剤の影響や，促進剤で皮膚表面を前処理した場 合の薬物透過性などを検討した結果, これらの高分子 促進剂は低分子系とは異なり, 皮膚内部の脂質層には 作用せず皮虔表面の性質を変化させることにより促進 効果を発現していることが判明した。

\section{5. おわりに}

以上述べたように，われわれが開発してきた高分子 促進剂は皮膚表面に作用し, 角質層中の拡散性には影 響を及ぼさずに特徵的に基剤から皮膚への薬物の分配 のみを高めていることから, 既存の低分子量の促進剂 とは作用機序が根本的に異なることが明らかとなっ た。すなわち, 高分子量なるがゆえに皮膚内部に浸透 せず内部の脂質構造に影響しないため, 皮膚刺激性が
なく薬物のみを吸収促進させる理想的な経皮吸収促進 剂になるものと期待される。 また, 上記の PDMS 化 合物は, シリコーン化合物の特徵を生かした経皮吸収 促進剤としての新たな用途を拓くものである.

\section{文献}

1) A.F. Kydonieus: Transderal Delivery of Drugs, Vol. 1, CRC Press, Boca Raton, Florida, p.3 (1987)

2) R. Woodford and B.W. Barry: J. Toxicol. ${ }^{-C u t . ~ \& ~}$ Ocular Toxicol., 5, 167 (1986)

3）森本 憲, 杉林堅次, 非経口剂加らの吸収, 粟津荘司, 小 泉 保編: 最新生物薬剂学, 南江堂, p.58 (1991)

4) P. Catz and D.R. Friend: J. Controlled Release, 12, $171(1990)$

5) H. Okamoto, M. Ohyabu, M. Hashida, H. Sezaki : J. Pharm. Pharmacol., 39, 531 (1987)

6) T. Yano, N. Higo, K. Furukawa, M. Tuji: Ther. Res., 10, 969 (1989)

7) Y. Akitoshi, K. Takayama, Y. Machida, T. Nagai : Drug Design and Delivery, 2, 239 (1988)

8) G.L. Flynn, B. Stewart: Drug Dev. Res., 13, 169 (1988)

9) T. Aoyagi, O. Terashima, N. Suzuki, K. Matsui and Y. Nagase, : J. Controlled Release, 13, 63 (1990)

10) T. Aoyagi, O. Terashima, Y. Nagase, K. Matsui: Polymer, 32, 2106 (1991)

11) T. Aoyagi, Y. Takamura, T. Nakamura, Y. Nagase : ibid, 33, 1530 (1992)

12) T. Aoyagi, Y. Takamura, T. Nakamura, Y. Yabuchi and Y. Nagase: ibid, 33, 2203 (1992)

13) T. Aoyagi, T. Nakamura, Y. Yabuchi, Y. Nagase: Polym. J., 24, 545 (1992)

14) T. Aoyagi, T. Nakamura and Y. Nagase: Polym. J., 24, 375 (1992)

15) T. Aoyagi, T. Akimoto, Y. Nagase: Makromol. Chem., 193, 2821 (1992)

16) Y. Nagase, T. Aoyagi, T. Akimoto and T. Fuchikami : Makromol. Chem., Rapid Commun., 13, 441 (1992)

17）青柳隆夫, 中村倫子, 長瀬 裕: 高分子論文集, 49, 839 (1992)

18）青柳隆夫: 生体材料, 11，42（1993）

19）杉林堅次: 薬物動態, 2, 71 (1987)

20) T. Higuchi : J. Soc. Cosmetic Chemists, 11, 85 (1960)

21) R.J. Scheuplein: J. Invest. Derm., 48, 79 (1967)

22) J.W. Wiechers, R.A. De Zeeuw: Drug Design and Discovery, 6, 87 (1990)

23) T. Aoyagi, M, Yamamura, N. Suzuki, K. Matsui, Y. Nagase : ibid, 8, 37 (1991)

24) T. Aoyagi, M. Yamamura, K. Matsui, Y. Nagase: ibid, 8, 47 (1991) 